\section{CHANGE IN CROPPING PATTERN AND SUSTAINABILITY OF THE AGRARIAN ECONOMY OF KASARAGOD DISTRICT, KERALA}

\begin{abstract}
The statistical profile of Kasaragod district experienced changes in cropping pattern. This created imbalance in the cropping system and had a serious economic and environmental impact on the farm sector and the sustainability of the agrarian economy. Changing cropping pattern and the consequent application of chemical fertilisers and pesticides heavily resulted in the depletion of inherent macronutrients, plant nutrients and micronutrients of the soil. There is a concern on the deterioration of quantity and quality of surface and groundwater. Sustainability has three important components: continued profitability, soil stability overtime and absence of adverse impact on the environment. In this context, the sustainability of the crop sector and the agrarian economy of Kasaragod district in Kerala is analysed on three grounds: decline in soil fertility status, decrease in the groundwater level and decline in total factor productivity growth. The analysis reveals decrease in soil fertility status in different crop growing areas with very high in rubber cropped areas, very low average groundwater level in rubber cropped areas compared to other cropped areas and deceleration in the total factor productivity growth in the crop sector of the district.
\end{abstract}

\section{Introduction}

Kasaragod was made as a separate district on $24^{\text {th }}$ May 1984 in the northern most part of the State of Kerala. The land use pattern in the district during the last few decades experienced change in cropping pattern. Data on the area under major crops show that paddy cultivation decreased from 9158 hectares in 2000-01 to 4205 hectares in 2013-14, the area under cashew nut cultivation decreased from 20448 hectares in 2000-01 to 7811 hectares in 2013-14, the area under tapioca cultivation decreased from 1373 hectares in 2000-01 to 331 hectares in 201314; whereas the area under rubber cultivation increased from 22232 hectares in 2000-01 to 33705 hectares in 2013-14. During 1985-86 the order of the first six crops was coconut, cashew nut, paddy, pepper, rubber and areca nut in the descending order of shares to the

* Head, Post Graduate Department of Economics, EKNM Government College, Elerithattu, Nilishwar, Kasaragod, Kerala, India, E-mail: narankarun@gmail.com 
total cropped area. But in 2013-14, the first six crops were coconut, rubber, areca nut, cashew nut, pepper and paddy. Rubber came to the second position by pushing paddy to the sixth position. The main crops losing area between 1985-86 and 2013-14 were paddy and tapioca.

The changing cropping pattern created imbalances in the cropping system and had a serious economic and environmental impact on the farm sector and therefore, the sustainability of the agrarian economy requires serious consideration. The increasing conversion of paddy lands and the expansion of rubber will bring out the main thrust of the ecological transformation (Srikumar Chattopadhyay, 2015). The over-exploitation of irrigation facilities adversely affected the water conservation. Changing cropping pattern and the consequent application of chemical fertilisers and pesticides heavily resulted in the depletion of inherent macronutrients, plant nutrients and micronutrients of the soil. There is a concern on the deterioration of quantity and quality of surface and groundwater. Hence it is felt that some of the indicators of sustainability or unsustainability like decline in yield, total factor productivity and native soil fertility, depletion in the quantity and quality of surface and groundwater resource, etc., are most relevant in the sustainability of the agrarian economy. Hence the following are the two specific objectives of this paper.

1. To analyse the changes in cropping pattern in the Kasaragod district of Kerala;
2. To examine how changes in cropping pattern affected the sustainability of the agrarian economy of the district.

\section{Methodology}

The study was carried out mainly by collecting secondary data from various publications of the Government of Kerala like Economic Review, Statistics for Planning, Agricultural Statistics, Season and Crop Reports and Cost of Cultivation of Important Crops. Data were also collected from the Analytical Register, Assistant Soil Chemist Office (Kasaragod), Soil Fertility Card, Vasutha Programme, Kasaragod District Panchayat, Groundwater Department (Kasaragod) and Package of Practices, Kerala Agricultural University, Trissur, etc.

There are no quick tests to indicate sustainability or unsustainability of the cropping system and the agrarian economy. At present some of the indicators of sustainability or unsustainability of the cropping system are widely used. They are (i) decline in yield, (ii) decline in total factor productivity, (iii) decline in native soil fertility and (iv) decline in the quantity of underground water (Rajendra Prasad, 1998). In this study measurement of sustainability of the cropping system and the agrarian economy of Kasaragod district is on the basis of the last three indicators.

Decline in Total Factor Productivity: This has been widely accepted as an indicator of lack of sustainability of the production system. The farming system and agrarian economy of any 
country or region are sustainable if they can maintain Total Factor Productivity Growth (TFPG) overtime (Pradumankumar et al., 2008). The TFPG is classified into three categories, viz., (i) stagnant (less than zero per cent TFPG rate), (ii) less than one per cent TFPG rate and (iii) more than one per cent TFPG rate. In this study deceleration in TFPG has been taken as a proxy of unsustainability.

Total Factor Productivity measures the extent of increase in the total output, which is not accounted for by increases in the total inputs. Total Factor Productivity is defined as the ratio of an index of aggregate output to an index of aggregate input. The DivisiaTornqvist index of Total Factor Productivity is commonly used (Amarender Reddy A, 2009) for computing total output, total input and total factor productivity by the farm sector and is outlined below:

(i) Total Output Index (TOI)

$\mathrm{TOI}_{\mathrm{t}} / \mathrm{TOI}_{\mathrm{t}-1}=\bigoplus_{\mathrm{j}}\left(\mathrm{Q}_{\mathrm{jt}} / \mathrm{Q}_{\mathrm{jt}-1}\right)^{1 / 2}\left(\mathrm{R}_{\mathrm{jt}}+\mathrm{R}_{\mathrm{jt}-\mathrm{I}}\right)$ $=A_{t}$

(ii) Total Input Index (TII)

$\mathrm{TIl}_{\mathrm{t}} / \mathrm{TI} \|_{\mathrm{t}-1}=\mathrm{D}_{\mathrm{i}}\left(\mathrm{X}_{\mathrm{it}} / \mathrm{X}_{\mathrm{it}-1}\right)^{1 / 2}\left(\mathrm{~S}_{\mathrm{it}}+\mathrm{S}_{\mathrm{it}-1}\right)$ $=\mathrm{B}_{\mathrm{t}}$ (2)

Where,

$\mathrm{R}_{\mathrm{jt}}=$ Share of the $\mathrm{j}^{\mathrm{th}}$ crop output in total revenue in the year $t$,

$\mathrm{R}_{\mathrm{jt}-1}=$ Share of the $j^{\text {th }}$ crop output in total revenue in $\mathrm{t}-1$ year,

$\mathrm{Q}_{\mathrm{jt}}=$ Output of jth crop in year $\mathrm{t}$,

$\mathrm{Q}_{\mathrm{jt}-1}=$ Output of jth crop in year $\mathrm{t}-1$,

$\mathrm{S}_{\mathrm{it}}=$ Share of input $\mathrm{i}$ in total input cost in year $t$,

$S_{i t-1}=$ Share of input $i$ in total input cost in year $\mathrm{t}-1$,

$\mathrm{X}_{\text {it }}=$ Quantity of input $\mathrm{i}$ in year $\mathrm{t}$,

$\mathrm{X}_{\mathrm{it}-1}=$ Quantity of input $\mathrm{i}$ in year $\mathrm{t}-1$,

$\mathrm{t}=$ Time period.

Total output and input index in period

$t$ was computed from (1) and (2) as follows:

TOI $(\mathrm{t})=\mathrm{A}_{1} \mathrm{~A}_{2}$ $A_{t}$

TII (t) $=B_{1} B_{2}$ $B_{t}$

Total Factor Productivity Index (TFP)

$\operatorname{TFP}_{\mathrm{t}}=\left(\mathrm{TOI}_{\mathrm{t}} / \mathrm{TII}_{\mathrm{t}}\right)$

Equations (3) to (5) provide the index of total output, total input and total factor productivity, respectively for period ' $t$ '.

For constructing the total input index, eight inputs (human labour, animal labour, machine labour, farm yard manure, chemical fertilisers, irrigation, land and repair and maintenance) were included. Human labour input was measured as the total number of workers employed in agriculture, animal labour was measured as the number of adult bullocks and male buffalos, machine labour input as the number of four-wheeler tractors, farm yard manure input as the number of livestock, chemical fertiliser input was measured as the total NPK fertilisers, irrigation was measured as the area under irrigation, land was measured as gross cropped area and repair and maintenance charge as the number of pump sets. The farm harvest prices and production of crops at district level were used to compute the output index. The total factor productivity index was computed by dividing the output 
index by the input index for the district. The input, output and total factor productivity growth rates were done by fitting the exponential trend equation model to the input, output and total factor productivity indices, respectively.

$$
Y=a b^{t}
$$
the formula:

The growth rate (GR) is computed using

$$
G R=(\text { Antilog } b-1) 100
$$

The $F$ test has been applied to test the significance of $b$.

Decline in Native Soil Fertility: Decline in native soil fertility, deficiency of plant nutrients and decline in micronutrients are the three main indicators for the unsustainability of land. Among these three, the first one was considered in this study. Decline in the native soil fertility status is analysed by taking the soil fertility status in different crop growing areas (paddy, coconut, areca nut and rubber) and is worked out from the analytical register and assistant soil chemist office of the district.

\section{Decline in the Quantity of Underground Water:}

Crop-wise average groundwater levels in different years were worked out from the data collected from the groundwater department to analyse the decline in the quantity of groundwater level. Eighteen monitoring stations, which were functioning from 1978 onwards, out of 53 dug well stations and 13 monitoring stations which were functioning from 1998 onwards out of 21 bore-well stations in the district were selected for data analysis. Crop-wise analysis was restricted to areca nut, coconut, paddy and rubber.

Extent of Crop Diversification: Herfindahl Index $(\mathrm{HI})$ is used to measure the extent of crop diversification and is calculated by taking sum of squares of acreage proportion of each crop to the total cropped area.

$$
\mathrm{HI}=\sum_{i=1}^{N} \mathrm{p}^{2}
$$

Where, $\mathrm{N}$ is the total number of crops and $P_{i}$ represents acreage proportion of the $i^{\text {th }}$ crops to total cropped area. Herfindahl Index is a measure of concentration and Diversification Index (DI) is calculated by subtracting it from one.

$$
\text { Diversification Index (DI) }=1-\mathrm{HI}
$$

\section{Results, Analysis and Discussion}

Change of Cropping Pattern in the District: The kind and sequence of crops grown over a period of time under specified soil conditions can be described as a cropping system. It may be a pattern of regular rotation of different crops or crops composition. The land can be sown or planted under a single crop during one season (monocropping) or under two crops in a year (double-cropping) or even more than two crops in the same piece of land in a crop year (multiple-cropping). Cropping pattern is a manifestation of cropping system (Rajan KV and Narayanamoorthy A, 2000). India is endowed with diverse climatic, edaphic and socio-economic conditions and has given rise to many location-specific cropping systems. 
Table 1: Changes in the Area Under Major Crops in Kasaragod District (1985-86 to 2013-14)

\begin{tabular}{|cccccccccccc|}
\hline S. No. & Year & \multicolumn{1}{c}{ Paddy } & Coconut & Areca nut & Rubber & Pepper Cashew nut & Tapioca & Ginger & Banana \\
\hline 1 & $1985-86$ & 22336 & 34977 & 8907 & 13200 & 9267 & 28397 & 5520 & 557 & 1824 \\
2 & $1990-91$ & 14292 & 44334 & 12269 & 18308 & 6803 & 24739 & 2433 & 166 & 2466 \\
3 & $1995-96$ & 11659 & 60197 & 12710 & 19280 & 6625 & 24560 & 1485 & 170 & 3027 \\
4 & $2000-01$ & 9158 & 59073 & 13515 & 22232 & 6229 & 20448 & 1373 & 139 & 3539 \\
5 & $2005-06$ & 6030 & 58088 & 17622 & 25374 & 6672 & 18068 & 576 & 56 & 3305 \\
6 & $2006-07$ & 5323 & 58236 & 14910 & 26620 & 6657 & 14518 & 503 & 60 & 3192 \\
7 & $2007-08$ & 5164 & 57057 & 15060 & 28230 & 6660 & 11667 & 452 & 65 & 2801 \\
8 & $2008-09$ & 4991 & 52266 & 14927 & 29380 & 5407 & 9487 & 245 & 17 & 2098 \\
9 & $2009-10$ & 4394 & 54224 & 15256 & 30624 & 4764 & 8205 & 389 & 22 & 2177 \\
10 & $2010-11$ & 4155 & 56174 & 18039 & 31740 & 6830 & 6803 & 335 & 22 & 2283 \\
11 & $2011-12$ & 3857 & 59656 & 19552 & 32650 & 2729 & 8250 & 292 & 23 & 2459 \\
12 & $2012-13$ & 3514 & 58836 & 18937 & 32650 & 2707 & 7981 & 274 & 20 & 2494 \\
13 & $2013-14$ & 4205 & 61836 & 19488 & 33705 & 2927 & 7811 & 331 & 29 & 2504 \\
\hline
\end{tabular}

Source: Computed from (i) Statistics for Planning (various issues), Department of Economics and Statistics, Govt. of Kerala, Thiruvananthapuram. (ii) Economic Review (various issues) and State Planning Board, Govt. of Kerala, Thiruvananthapuram.

The cropping pattern scenario of the district for the period $1985-86$ to $2013-14$ is shown in Table 1. In terms of their claim on total cropped area, the leading crops in the district were paddy, coconut, areca nut, rubber, pepper, cashew nut, tapioca, ginger, banana and other plantations. Together they accounted for 91.67 per cent of the gross cropped area. It would be noted from Table 1 that percentage of area under paddy, tapioca, cashew nut, pepper and ginger showed a decreasing trend and other crops an increasing trend during different years. In recent years, rubber seems to be replacing paddy and other crops in the midland and highland areas. Various price and non-price factors influenced this allocation of land to different crops. This included the harvest price of crops, availability of minimum support price, price of the competing crop, prices of inputs and availability of credit. Similarly, non-price factors like yield, improved seeds, rainfall, irrigation facilities and extension services also contributed to the decline in area under food crops and increase in the area under coconut, rubber and areca nut in the district.

\section{Extent of Crop Diversification in the District:}

The concept of crop diversification conveys different meanings to different people at different levels. Diversification means moving away from growing a single crop to a number of crops, a shift of resources from farm to non-farm activities, use of resources in a larger mix of diverse and complementary activities within agriculture and a movement of resources from low value crops to high value crops (Rajeev Sharma, 2007). In practice it is a relative concept and usually analysed in terms of degree of diversification. 
Table 2: Cropping Pattern According to Land Use Statistics in Kasaragod District

(Percentage to Total Cropped Area)

\begin{tabular}{|clcccccc|}
\hline S. No. & Crop & $1985-86$ & $1990-91$ & $1995-96$ & $2000-01$ & $2005-06$ & $2013-14$ \\
\hline 1 & Paddy & $16.19(3)$ & $10.08(4)$ & $7.39(5)$ & $5.94(5)$ & $3.89(6)$ & $2.90(6)$ \\
2 & Coconut & $25.35(1)$ & $31.28(1)$ & $38.15(1)$ & $38.33(1)$ & $37.52(1)$ & $42.67(1)$ \\
3 & Arecanut & $6.46(6)$ & $8.65(5)$ & $8.05(4)$ & $8.77(4)$ & $11.38(4)$ & $13.45(3)$ \\
4 & Rubber & $9.57(4)$ & $12.92(3)$ & $12.22(3)$ & $14.42(2)$ & $16.39(2)$ & $23.26(2)$ \\
5 & Pepper & $6.72(5)$ & $4.79(6)$ & $4.19(6)$ & $4.04(6)$ & $4.31(5)$ & $2.93(5)$ \\
6 & Cashewnut & $20.58(2)$ & $17.45(2)$ & $15.56(2)$ & $13.26(3)$ & $11.67(3)$ & $5.39(4)$ \\
7 & Tapioca & $4.00(7)$ & $1.72(8)$ & $0.94(8)$ & $0.89(8)$ & $0.37(8)$ & $0.23(8)$ \\
8 & Ginger & $0.40(9)$ & $0.12(9)$ & $0.11(9)$ & $0.09(9)$ & $0.04(9)$ & $0.02(9)$ \\
9 & Banana and & & & & & & \\
& other plantains & $1.32(8)$ & $1.74(7)$ & $1.92(7)$ & $2.29(7)$ & $2.13(7)$ & $1.73(7)$ \\
10 & TC A & 100.00 & 100.00 & 100.00 & 100.00 & 100.00 & 100.00 \\
\hline
\end{tabular}

Note: Figures in brackets show ranks.

Source: Computed from (i) Statistics for Planning (various issues), Department of Economics and Statistics, Govt. of Kerala, Thiruvananthapuram. (ii) Economic Review (various issues), State Planning Board, Govt. of Kerala, Thiruvananthapuram.

Table 2 reveals the decline in the percentage of area under food crops and increase in non-food crops. During 1985-86 to 2013-14 percentage shares of food crops like paddy and tapioca declined tremendously; whereas non-food crops like rubber, coconut, areca nut, etc., increased. The picture in Table 2 clearly reveals that there has been diversification of crop area from food crops to non-food crops and it is a clear evidence of substitution of area from food to non-food crops.
During 1985-86 the order of the first five crops was coconut, cashew nut, paddy, rubber and pepper, in the descending order of shares to the total cropped area. Table 2 reveals that in 2013-14, the first five crops were coconut, rubber, areca nut, cashew nut and pepper. Rubber came to the second position by pushing paddy to the sixth. Coconut, rubber and areca nut together constituted 80 per cent of the total cropped area. The main crops losing area were paddy, cashew nut and tapioca.

Table 3: Crop Diversification Indices for Kasaragod District in Different Years (1985-86 to 2013-14)

\begin{tabular}{|ccc|}
\hline S. No. & Year & Crop Diversification Index \\
\hline 1 & $1985-86$ & $0.848(0.152)$ \\
2 & $1990-91$ & $0.858(0.142)$ \\
3 & $1995-96$ & $0.861(0.139)$ \\
4 & $2000-01$ & $0.863(0.137)$ \\
5 & $2005-06$ & $0.866(0.134)$ \\
6 & $2009-10$ & $0.869(0.131)$ \\
7 & $2012-13$ & $0.872(0.128)$ \\
8 & $2013-14$ & $0.874(0.126)$ \\
\hline
\end{tabular}

Note: Figures in brackets show Herfindahl Index. 
Table 3 clearly shows the shift from food crops, mainly paddy and tapioca, to in favour of tree crops such as rubber, areca nut and coconut in the district, which was supported by the diversification index shown in Table 3. It is observed that the transformed values of Herfindahl Index were lower in the initial years of study. This implies less diversification in the initial years and higher values in the later years, viz., 2005-06, 200910 and 2013-14, which indicates more diversification.

Decline in the Soil Fertility Status: There are several studies that say intensive cropping with high doses of inorganic fertilisers has led to deficiencies in the soil fertility status in several parts of India. It is an important indicator to measure the quality and health of the soils which determines agricultural sustainability and environmental quality (Karunakaran N, 2014).

In the present analysis areas growing four crops (paddy, coconut, areca nut and rubber) were selected to measure the changes in the soil fertility. The evaluation of soil fertility on the basis of soil test results in these four crop based systems are done in two ways: analysing first by macronutrients (NPK) and second by the pH status(Figures 1 to 4).

Figure 1: Soil pH in Major Crop Growing Areas of Kasaragod District

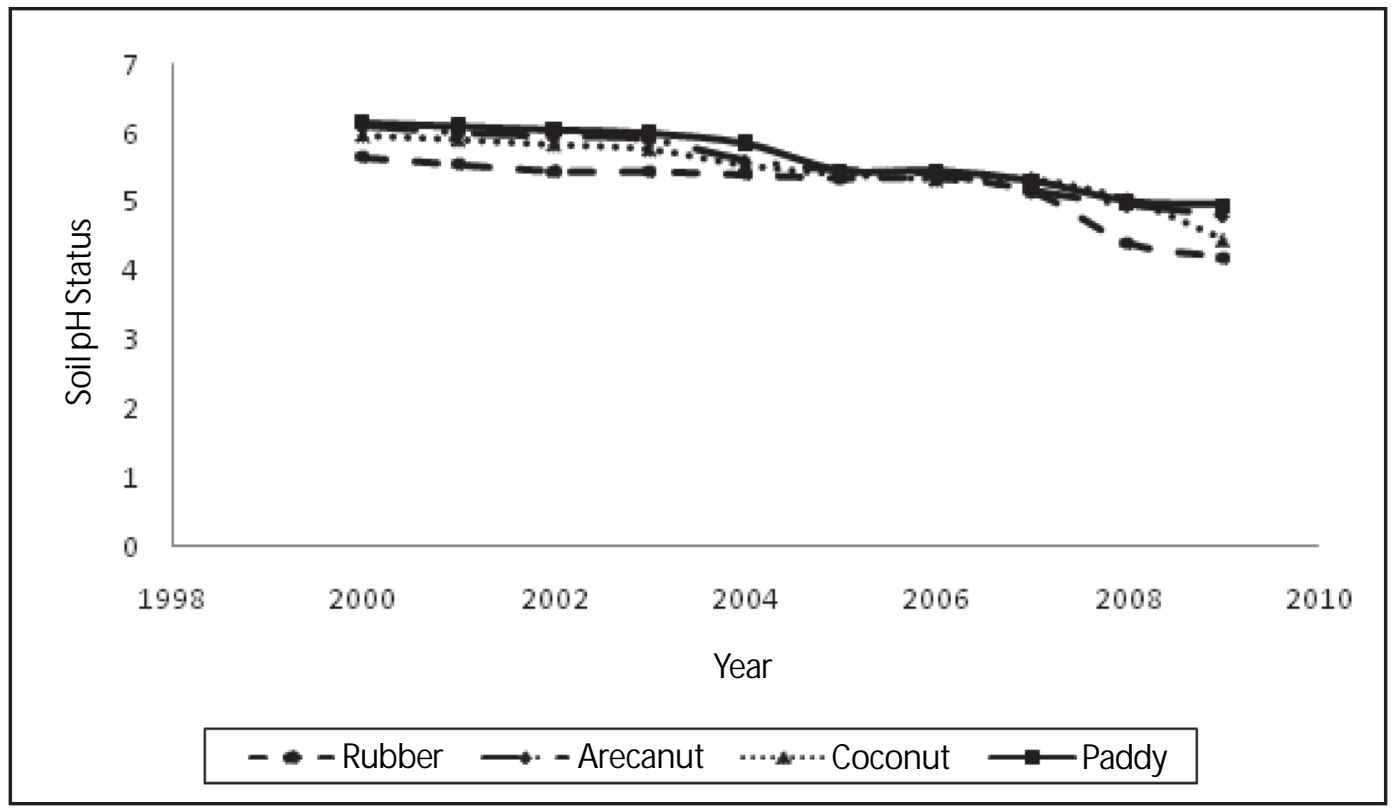

Journal of Rural Development, Vol. 36, No. 3, July-September : 2017 
Figure 2: Soil N Status in Major Crop Growing Areas of Kasaragod District

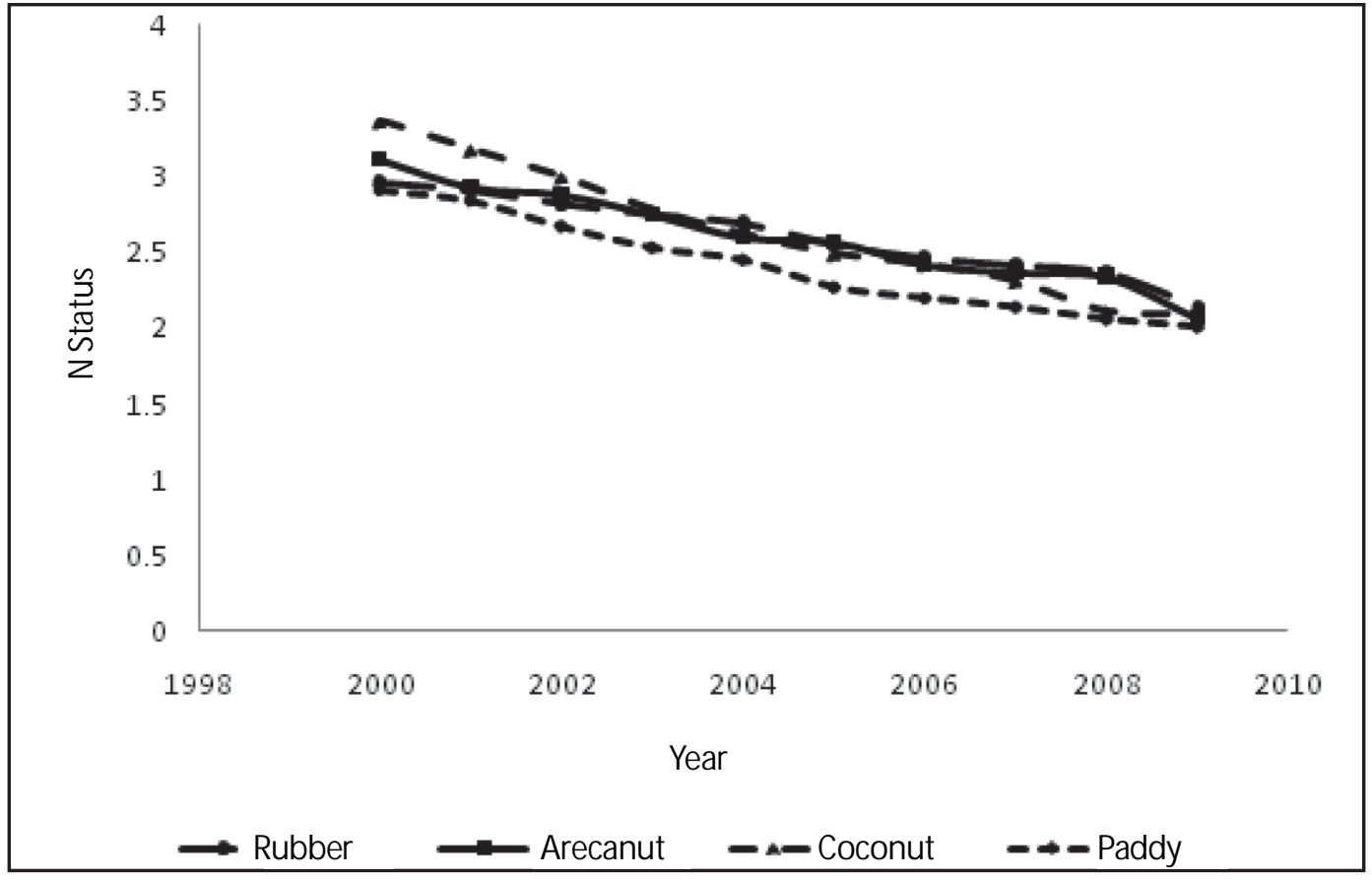

Figure 3: Soil P Status in Major Crop Growing Areas of Kasaragod District

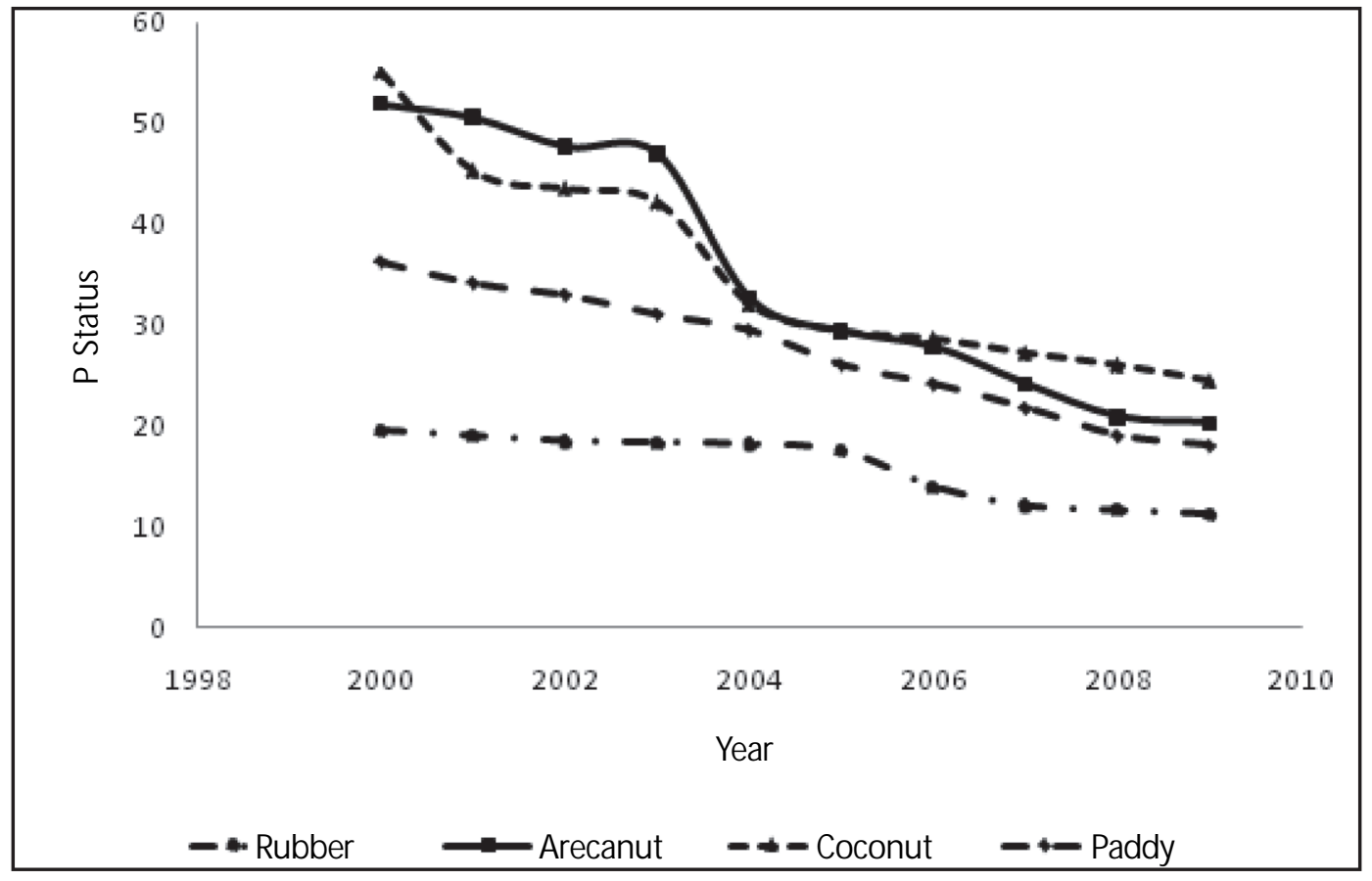

Journal of Rural Development, Vol. 36, No. 3, July-September : 2017 
Figure 4: Soil K Status in Major Crop Growing Areas of Kasaragod District

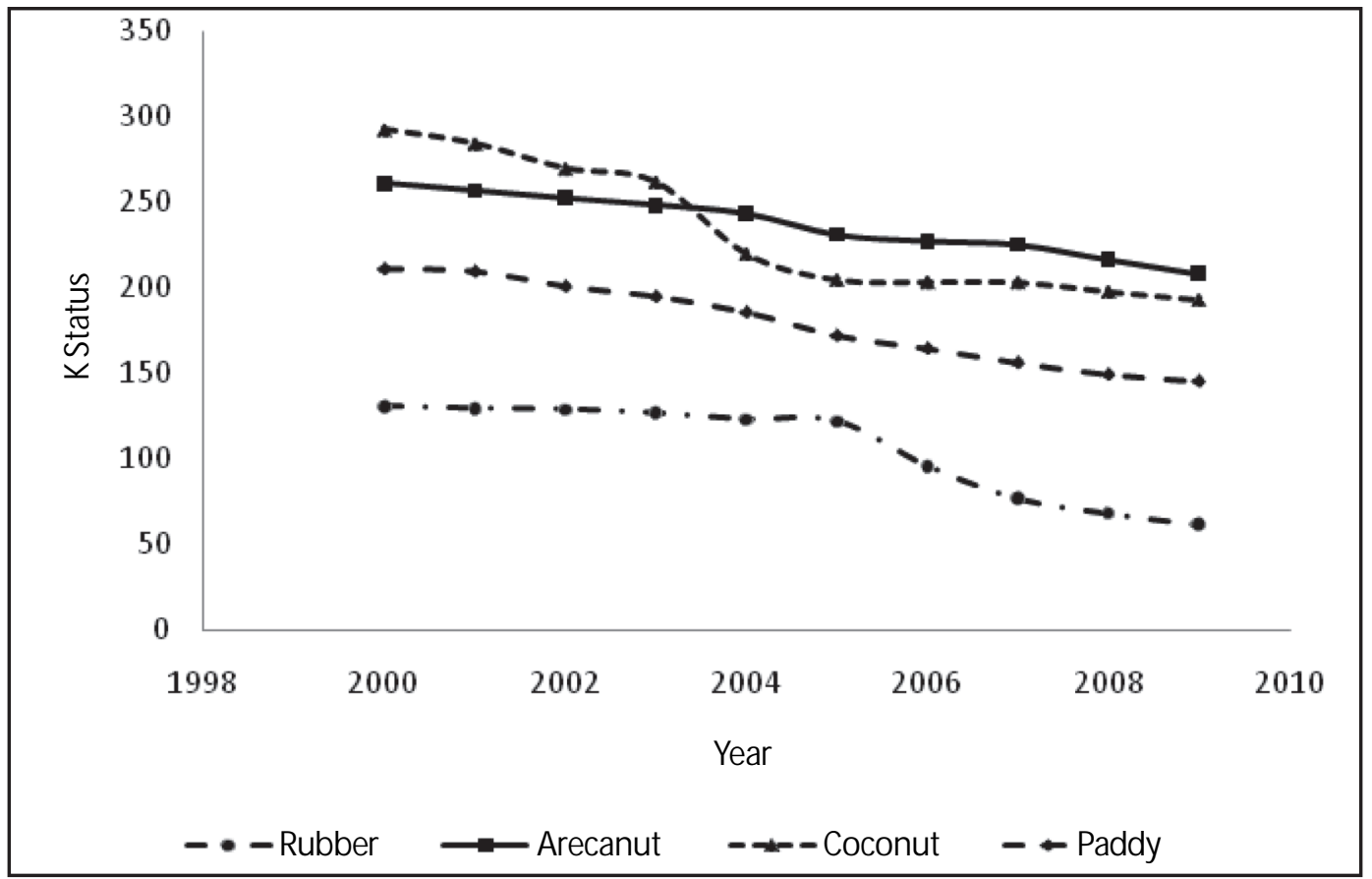

Figure 1 shows that there was decrease in the average soil $\mathrm{pH}$ status in all the crop growing areas; but the decline was severe in rubber cropped systems. Figures 2 to 4 derive the continuous decline of soil fertility and soil health in general and the deterioration of $P$ and $\mathrm{K}$ soil status in particular to the rubber cropping system in the district. It is also found that $P$ and $K$ elements are low in the rubber plantations of the district.

Decrease in the Groundwater Level: There is wide concern in the world that groundwater resources are deteriorating in the long-term both in quantity and quality. Studies on groundwater balance in the State have observed that the water table has been receding in many parts of Kerala (Karunakaran $\mathrm{N}, 2012$ ). The depletion of underground water has important implications from the economic angle as well as from the point of view of sustainability of agricultural system. Though many factors are responsible for groundwater decrease, the problem is being largely linked to the changes in cropping pattern. To study the effect of changes in cropping pattern on groundwater depletion in the district, average groundwater level in four crop growing (paddy, coconut, areca nut and rubber) areas were worked out. 
Figure 5: Average Groundwater Level in Different Crop Growing Areas of Kasaragod District



Figure 5 shows crop-wise average groundwater level in different years in the district which reveals that the average groundwater level of dug wells in the paddy, areca nut and coconut growing areas increased and rubber areas decreased. The average groundwater level in the rubber crop growing areas was very low (below 4 metres) compared to other crop growing areas. It is observed that the recharge of water in the rubber cropped areas was very low compared to other crops and the discharge of water was high.
Total Factor Productivity Growth in the Crop

Sector: Productivity growth in agriculture is both a necessary and a sufficient condition for development and total factor productivity is an important measure to evaluate the performance of any production system and sustainability of a growth process (Amarender Reddy A, 2009). The cropping system is sustainable if it can maintain total factor productivity growth over time. 
Table 4: Total Factor Productivity Growth (TFPG) in the Crop Sector in Kasaragod District (1985-86 To 2009-10)

\begin{tabular}{|c|c|c|c|c|c|c|c|c|}
\hline & $\begin{array}{c}-91 \text { to } 199 \\
\text { o per ann } \\
0.308\end{array}$ & & & $\begin{array}{l}01 \text { to } 2 \\
\text { per anr } \\
-0.489\end{array}$ & & & $\begin{array}{r}86 \text { to } 2 \\
\text { per an } \\
-0.757\end{array}$ & \\
\hline Percentag & share of & | Facto & oductivit & (P) in 0 & ut growt & of the cro & ector & \\
\hline & Ns & & & $\mathrm{Neg}$ & & & $\mathrm{Neg}$ & \\
\hline Average a & nual gron & n Outp & Input an & $P$ of th & op secto & & & \\
\hline $\begin{array}{l}\text { Output } \\
\text { (\%) }\end{array}$ & $\begin{array}{c}\text { Input } \\
(\%)\end{array}$ & $\begin{array}{l}\text { TFP } \\
(\%)\end{array}$ & $\begin{array}{c}\text { Output } \\
(\%)\end{array}$ & $\begin{array}{c}\text { Input } \\
(\%)\end{array}$ & $\begin{array}{l}\text { TFP } \\
(\%)\end{array}$ & $\begin{array}{c}\text { Output } \\
\text { (\%) }\end{array}$ & $\begin{array}{c}\text { Input } \\
(\%)\end{array}$ & $\begin{array}{l}\text { TFP } \\
(\%)\end{array}$ \\
\hline $0.22 \mathrm{Ns}$ & $-0.09 \mathrm{Ns}$ & 0.308 & 0.622 & 1.111 & -0.489 & 1.502 & 2.259 & -0.757 \\
\hline
\end{tabular}

The studiesby KumarP and Mruthyunjaya (1992), Kumar P et al. (1998), Pradumankumar, et al. (2004), Srinivas T, et al. (2007), Amarender Reddy A (2009) and Karunakaran N (2015) highlighted that the total factor productivity growth of important crops was decelerating in different parts of India. It was argued that if appropriate measures were not undertaken to address the problem of sustainability and natural resource degradation, the future growth of agriculture in such areas would be jeopardised.

Table 4 shows that in the district, the share of TFP in the output growth was negative during the time period $1985-86$ to 2009-10. The period-wise analysis also derived deceleration in the total factor productivity growth. Therefore, agricultural growth has been an important issue in the context of crop diversification in the district.

\section{Conclusion}

There are no quick tests to indicate sustainability or unsustainability of crop sector and the agrarian economy in the context of crop diversification. Sustainability analysed in terms of continued profitability, soil stability overtime and absence of adverse impact on environment has the following results revealed in the recently exhibited crop diversification of Kasaragod district.

(i) Decline in soil fertility status measured by calculating the average soil fertility status of four crop growing areas of paddy, coconut, areca nut and rubber by evaluating and analysing $\mathrm{pH}$ status and NPK status showed that $\mathrm{pH}$ status was decreasing over the years in all crop growing areas and was severe in rubber cropped systems; the continuous decline of soil health and soil fertility in general and the decline of $P$ and $K$ soil status in particular were observed in the rubber cropped areas compared to other cropped areas.

(ii) Decrease in the average groundwater level in different crop growing areas revealed that water level in rubber crop growing areas was very low compared to paddy, coconut and areca nut. 
(iii) The performance of crop sector and efforts for accelerating the pace of total measured in terms of total factor factor productivity growth and at the same productivity growth in the district time sufficient caution has to be exercised to indicated negative growth rates during conserve natural resources and promote the period.

These negative indicators primarily arise institutional infrastructure. It provides physical inputs and induces technical change. More as a result of the changing cropping pattern in Kasaragod district, experienced in the past public investment in irrigation, infrastructure years, seems to be more serious and question development like road and electricity, research and extension, efficient use of water and the sustainability of the agrarian economy. This micro, macro and plant nutrients are also calls for better resource management strategy essential in the district. 


\section{References}

1. Alfred E, Hartemink (2006), "Soil Fertility Decline, Definitions and Assessment", Encyclopaedia of Soil Science DOI: 101081, pp. 1618-1621.

2. Amarender Reddy, A (2009), "Research Report on Factor Productivity and Marketed Surplus of Major Crops in India: An Analysis of Orissa State," submitted to Planning Commission, Govt. of India, Administrative Staff College of India, Bellavista, Hyderabad, pp. 16-17.

3. District Panchayat, Kasaragod (2009), "Soil Fertility Card-2009", Panchayat-wise Soil Fertility Card, No.1 to 39.

4. Goswami, SN and Challa, O (2006), "Land Use Scenario in Meghalaya- An Exploratory Analysis", Agricultural Situation in India, 63(6), pp: 369-385.

5. Government of Kerala (2014),"Economic Review," State Planning Board, Thiruvananthapuram, pp. 19-48.

6. Karunakaran, N (2012), "Diversification of Crops and Groundwater Depletion in Kasaragod District, Kerala", Pragati, 122, pp. 41-49.

7. Kumar, P; Joshi, PK; Johansen, C and Asokan, M (1998), "Sustainability of Rice-Wheat Based Cropping System in India," Economic and Political Weekly, Vol. 33, pp. A 152-A-158.

8. Kumar, P and Mruthyunjaya (1992), "Measurement and Analysis of Total Factor Productivity Growth in Wheat," Indian Journal of Agricultural Economics, 47 (7), pp. 451-458.

9. Pradumankumar, Anjanikumar and Surabhi Mittal (2004), "Total Factor Productivity of Crop Sector in the Indo-Gangetic Plain of India: Sustainability Issues Revisited", Indian Economic Review, 39 (1), pp. 169-201.

10. Pradumankumar, Surabhi Mittal and Mahabub Hossain (2008), "Agricultural Growth Accounting and Total Factor Productivity in South Asia: A Review and Policy Implications," Agricultural Economics Research Review, 21(2), pp. 145-172.

11. Rajan, KV and Narayanamoorthy, A (2000), "Cropping System:State of the Indian Farmer"- Vol. 9, Crops and Cultivation, Ministry of Agriculture, Govt. of India and Academic Foundations, New Delhi, pp. 103-159.

12. Rajeev Sharma (2007), "Agricultural Development and Crop Diversification in Jammu and Kashmir: A District Level Study Patterns, Processes and Determinants," Review of Development and Change, 12 (2), pp. 217-250.

13. Rajendra Prasad (1998), "Cropping System and Sustainability of Agriculture", Crop Productivity and Sustainability- Shaping the Future (Ed), by Chopra VL, Singh KB and Anupam Varma, Oxford and IBH Publishing Co. Pvt. Ltd, New Delhi, pp: 619-630.

14. Srikumar, Chattopadhyay (2015), "Environmental Consequences of Rubber Plantations in Kerala," Discussion Paper No. 44, CDS, Thiruvananthapuram, pp. 1-54. 
15. Srikumar, Chattopadhyay, Asa Rani, L and Sangeetha, PV (2005), "Water Quality Variation as Linked to Land Use Pattern: A Case Study in Chalakkudy River Basin, Kerala", Current Science, 89 (12), pp. 2163-2169.

16. Srinivas T, Siju T and Edison, S (2007), "Measurement and Analysis of Total Factor Productivity Changes for Cassava in Kerala", Agricultural Situation in India, pp. 438-442. 